But before an injunction will issue, equity jurisdiction must be established..$^{{ }^{10}}$ Therefore a petitioner must exhaust his administrative and legal remedies before he may seek equitable relief, and it must also be shown that irreparable injury will be suffered if an injunction is not issued. ${ }^{x I}$ In cases not involving licenses the Hllinois courts have held that the availability of an extraordinary legal remedy will bar a suit for injunction, ${ }^{\mathrm{T}}{ }^{42}$ but it is uncertain whether these holdings apply when occupational licenses are involved. The courts have usually assumed that the revocation of an occupational license by an unauthorized administrative officer will result in irreparable injury. ${ }^{143}$ It has also been assumed that the mere holding of a hearing by an unauthorized professional committee will so injure an occupational licensee as to justify the issuance of an injunction. ${ }^{144}$ But an injunction will not issue to interfere with the exercise of the discretionary powers which an administrative agency is conceded to possess. ${ }^{145}$

Thus remedy by injunction supplements the use of mandamus, certiorari, and appeal in a scheme of judicial review which affords persons subject to the jurisdiction of occupational licensing authorities a degree of judicial review consistent with the successful performance by administrative officers of the functions allotted to them.

\title{
THE ADMISSIBILITY OF CHARACTER EVIDENCE IN DETERMINING SENTENCE
}

During the nineteenth and twentieth centuries American criminal legislation has shifted from the fixed sentence type of criminal statute to the discretionary

${ }^{140}$ Doe v. Jones, 327 Ill. 387 , I 58 N.E. 703 (1927); Fidelity Investment Ass'n v. Emmerson, 235 Ill. App. 9 (I924).

${ }^{14}$ But cf. Kalman v. Walsh, 355 Ill. 34 r, $x 89$ N.E. 315 (I934) (court discussed neither exhaustion nor inadequacy of legal remedies before granting injunctions); Ramsay v. Shelton, 329 Ill. 432,160 N.E. 769 ( $x_{928)}$ ).

${ }^{x_{42}^{2}}$ New Haven Clock Co. v. Kochersperger, I75 Ill. 383 , 5I N.E. 629 (I898); Fletcher v. Tuttle, I5I Ill. 4I, 37 N.E. 683 (1894); Rockford Amusement \& Refreshment Co. v. Baldwin, 252 Ill. App. I (1929).

${ }_{43}$ Notes $I 29$ and $x_{3} \circ$ supra.

544 Kalman v. Walsh, 355 Ill. 34I, 189 N.E. 3I5 (I934); Ramsay v. Shelton, 329 Ill. 432, I60 N.E. 769 (I928); State Bd. of Health v. Ross, I9I Ill. 87, 60 N.E. 8II (Igor). Contrast the attitude of the federal courts in analogous situations, discussed in Appealability of Interlocutory Orders of Independent Federal Administrative Agencies, 8 Univ. Chi. I. Rev. II3 (I94I).

${ }^{145}$ Klafter v. State Bd. of Examiners of Architects, 259 Ill. I5, I02 N.E. I93 (I9r3); see Fidelity Investment Ass'n v. Emmerson, 235 Ill. App. 9 (I924).

I In the seventeenth century practically all felonies called for the death sentence. $4 \mathrm{Bl}$. Comm. *98. In Blackstone's day Parliament had provided that the death sentence should be imposed in not less than 160 different crimes. Ibid., at * 17 . Indeed, it appears that variations in punishment according to the severity of the crime were only to be found in the manner in which the death sentence was to be imposed. Ibid., at ${ }^{*} 6 \mathrm{t},{ }^{*} 92,{ }^{*} 93,{ }^{*} 97$. 
sentence type of statute. ${ }^{2}$ This trend has been actuated by a corresponding shift in penal theory toward an increasing recognition of the rehabilitative function of imprisonment. ${ }^{3}$

The application of discretionary sentence statutes to trial procedure raises some difficult problems in regard to the admissibility of character evidence. Since a history of the criminal's dealings with society is an essential element in determining a proper sentence, the efficient operation of discretionary sentence statutes calls for evidence of the defendant's character - general reputation as well as evidence of specific acts of prior misconduct. Here, however, a conflict arises. Trial procedure jealously guards the history of the criminal's past from the jury in order that a man may not be convicted solely because of his past record. Thus the so-called undue prejudice rule excludes evidence of prior misconduct ${ }^{5}$ even though this evidence is relevant ${ }^{6}$ as to guilt or innocencerelevant in that it indicates an increased probability that the accused committed the crime. ${ }^{7}$

In practice, courts which have been faced with the problem of the admissibility of such evidence have found it necessary either to eliminate the protection given the accused by the undue prejudice rule by admitting the evidence ${ }^{8}$

${ }^{2}$ Few crimes today call for a fixed definite sentence. The great majority call for an indeterminate sentence. Note 29 infra. The crime of murder is punishable in most states by either death or life imprisonment. But in Illinois any term of years not less than fourteen may be imposed, or the death sentence may be rendered, upon conviction under a murder indictment. Ill. Rev. Stat. (I94I) c. 38, \$80r.

3 Mannheim, The Dilemma of Penal Reform 28 (I939); see Holmes, The Common Law 42-47 (188I).

4 Where a statute gives wide latitude to the court or jury in the matter of fixing sentence, the defendant's background, occupation, and past criminal record are elements which demand consideration in determining the proper sentence. People v. Riley, 376 Ill. 364,33 N.E. (2d) 872 (I94) ; Dalhover v. United States, 96 F. (2d) 355 (C.C.A. $7^{\text {th }}$ I938); People v. Popescue, 345 III. I42, I77 N.E. 739 (193x).

5 Such evidence is admissible in order to show knowledge, intent, design, or plan. 2 Wigmore, Evidence $\$ \$ 300-4$ (3d ed. I940); Commonwealth v. Robinson, I46 Mass. 57I, 16 N.E. $45^{2}$ (1888); cf. Rex v. Ellis, 6 B. \& C. 445 (K.B. 1826). It is also admissible for purposes of impeaching the defendant as a witness. 3 Wigmore, Evidence $\$ \$ 889-9 \circ$ ( $3 \mathrm{~d}$ ed. 5940 ), and cases there cited.

If the defendant calls witnesses to testify to his good character, the prosecution may also call witnesses in rebuttal to testify to his bad character. But the prosecution cannot offer evidence of specific misconduct for such a purpose. I Wigmore, Evidence $\$$ r93 (3d ed. x940), and cases there cited.

6 "A defendant's character, then, as indicating the probability of his doing or not doing the act charged, is essentially relevant." I Wigmore, Evidence $\$ 55$, at $45^{\circ}$ (3d ed. r940).

7 The undue prejudice rule is apparently unknown in continental law. Great weight is placed upon evidence of prior criminal conduct in continental proceedings. I Wigmore, Evidence $\$ 193$ (3d ed. 1940 ).

${ }^{8}$ Commonwealth v. Flood, 302 Pa. 190, 153 Atl. 152 (1930); Commonwealth v. Dague, 302 Pa. I3, $x_{52}$ Atl. 839 (1930); People v. Hong Ah Duck, 6r Cal. 387 (1882); see Kistler v. State, 54 Ind. 400, 404 (1876); Fields v. State, 47 Ala. 603 (1872). 
or to disregard the policy behind the discretionary sentence statutes by excluding the evidence.9

This apparent dilemma into which the courts have fallen is the result of a failure to distinguish between the function of trying the accused and the function of sentencing the criminal. This confusion seems to have originated during the transition in the early part of the nineteenth century from the common law procedure to the statutory procedure of determining sentence. Under the common law system the jury simply returned a verdict of guilty or not guilty ${ }^{\text {;0 }}$ the duty of measuring out the sentence rested with the court. The court, after the jury returned a verdict of guilty, heard additional character evidence before determining the sentence. ${ }^{\mathrm{Ix}}$ By statute in many jurisdictions the power of sentencing was taken from the court and vested in the jury. However, few courts recognized the necessity for separating the sentencing function from the trial function once both were vested in the jury. A rigorous application of the undue prejudice rule prevented character evidence, which formerly was presented to the judge in determining sentence, from ever reaching the jury. The common law principle that character evidence was relevant in determining the proper sentence was so completely forgotten through this blind application of the undue prejudice rule that such evidence has even been excluded from the court when the court was exercising its historical role of determining the sentence. ${ }^{\mathrm{I2}}$

Hence, while criminal theory was changing so that a flexibility became important with respect to fixing sentence, criminal procedure was fast hardening to the point where it was impossible for either the court or the jury to get adequate information before it in order to determine properly the period of confinement. Since criminal theory today proceeds upon the assumption that the purpose of confinement is rehabilitation, a return to the common law procedure would be desirable in order that the judge might have enough facts before him to determine the appropriate prison term.

If the trial and sentence-fixing functions are kept separate, even though they are to be performed by the same body, no violence need be done to the undue prejudice rule in the trial, while the sentencing body will have access to the essential facts at the sentencing stage. Thus, while certain forms of character

9 People v. Corry, 349 Ill. 122, 18I N.E. 603 (I93I); cf. Berry v. State, 5I Ga. App. 442, r80 S.E. 635 (1935); State v. Smith, I 29 Iowa 709, I06 N.W. 187 (I906); People v. Sickles, I56 N.Y. 54r, 5I N.E. 288 (I898).

so "By the common law, the jury determined merely the guilt or innocence of the prisoner; and, if their verdict was guilty, their duties were at an end..... The court alone determined what the punishment should be....." Fields v. State, 47 Ala. 603, 606 (1872). See Kistler v. State, 54 Ind. 400,403 ( 1876$)$.

"r Rex v. Wilson, 4 Term Rep. 487 (K.B. I79r); Rex. v. Withers, 3 Term Rep. 428 (K.B. r789); Rex v. Bunts, 2 Term Rep. 683 (K.B. I788); see Kistler v. State, 54 Ind. $400 ; 403$ (I876); I Bishop, Criminal Law $\$ 934$ (gth ed. I923).

Is State v. Vennum, I49 Wash. 670, 272 Pac. 62 (I928); State v. Kendall, 200 Iowa 483, 203 N.W. 806 (1925); People v. Miller, 114 Cal. 10, 45 Pac. 986 (I8g6). 
evidence are excluded at trial because of the undue prejudice rule, ${ }^{x^{3}}$ there no longer exists any reason for excluding this type of character evidence at the sentencing stage after guilt has been established by plea or by verdict. ${ }^{14}$

However simple this solution might seem, it has been accorded scant attention by courts, counsel, or text writers. Indeed, some legislatures in passing discretionary sentence statutes have tied the court's hands by requiring the sentence to be returned with the verdict of guilty. 15

The distinction between the trial function and the sentencing function, however, has not gone entirely without recognition. Where a statute provides that under a plea of guilty the court is to pass sentence, most courts hold that character evidence may be presented before sentence is imposed..$^{16}$ The question of admissibility of specific acts of prior misconduct in such a situation was squarely presented to the Illinois Supreme Court in the case of People v. Popescue. ${ }^{\text {I7 }} \mathrm{It}$ was held that since there was no contention as to the defendant's guilt, there was no longer any compelling reason to apply the undue prejudice rule, a rule designed to protect the innocent, not the guilty. ${ }^{\mathrm{x}}{ }^{8}$ It was further held that such a hearing was not a trial but a process by means of which the court could gather the information necessary to exercise the wide discretion given it under the statute.

The decision in the Popescue case was followed in Dalhover v. United States, ${ }^{19}$ one of the rare instances in which, following a plea of guilty, a jury was impaneled for the purpose of rendering a sentence. In this case a sentence of death imposed by the jury after a plea of guilty to murder ${ }^{20}$ was upheld although an admission by the defendant that he had committed some 150 robberies had been admitted over objection. The court held that since guilt had been established

${ }_{3}$ I Wigmore, Evidence $\$ 55$ (3d ed. $x_{940)}$.

${ }^{14}$ Cason v. State, I6o Tenn. 267, 23 S.W. (2d) 665 (I930); Rex v. Bonnevie, 38 Nova Scotia 560 (I906); State v. Summers, 98 N.C. 702, 4 S.E. I 20 (I887); State v. Smith, 2 Bay (S.C.) 62 (1796); Rex v. Sharpness, I Term Rep. 228 (K.B. I786).

15 Ill. Rev. Stat. (r94I) c. 38, §8or; Ind. Stat. Ann. (Burns, I933) §9-I8Ig. Some complications arising from this type of statute are indicated in 9 Univ. Chi. L. Rev. 497 (r942), noting People v. Hicks, 287 N.Y. 165,38 N.E. (2d) 482 (I94r).

${ }^{26}$ People v. Hetherington, 379 Ill. 7 I, 39 N.E. (2d) 36r (r942); People v. Riley, 376 Ill. 364 , 33 N.E. (2d) 872 (I94I); People v. Popescue, 345 IIl. $x_{42}$, I77 N.E. 739 (I93I); Tractenberg v. United States, 293 Fed. 476 (App. D.C. I923); see Cason v. State, I60 Tenn. 267, 23 S.W. (2d) 665 (I930). It has been held incumbent upon the judge to inquire carefully into the defendant's past in order to discover if there is any evidence of a mitigating nature. People $v$. McWilliams, 348 Ill. 333, I80 N.E. 832 (I932). At common law evidence in mitigation or aggravation of the offense was also heard by the court following pleas of guilty. Rex v. Dignam, 7 A. \& E. 593 (K. B. 1837 ).

${ }^{17} 345$ Ill. $\mathrm{r}_{42}$, r77 N.E. 739 (r93r). $\quad{ }^{18}$ Notè 38 infra.

${ }^{19} 96$ F. (2d) 355 (C.C.A. 7 th r938), cert. den. 305 U.S. 632 (1938).

${ }^{20} \mathrm{~A}$ statutory charge of murder was involved, which arose out of a murder following a robbery of a national bank in violation of the Federal Banking Act, 48 Stat. 783 (1934), I2 . U.S.C.A. $\$ 588 \mathrm{c}(\mathrm{r} 936)$. 
by the plea, the defendant could no longer invoke the undue prejudice rule. But in Reppin v. People ${ }^{2 x}$ the Supreme Court of Colorado reversed and remanded a case in which upon a plea of guilty the jury had imposed a penalty of death after hearing of the defendant's previous criminal history. The two cases are irreconcilable. The Dalhover case is preferable in that it properly recognized the distinct function the jury was performing in this situation.

The common law principle of separating the trial from the sentencing function is also implicit in the more desirable form of habitual criminal statute. Most jurisdictions today have some form of habitual criminal statute ${ }^{22}$ providing for an increased punishment for the persistent offender. ${ }^{23}$ Since a series of prior convictions must be alleged and proved in order to secure the increased sentence, such evidence is likely to conflict with the undue prejudice rule unless the separation procedure of trial and sentence is followed. Most statutes are silent upon this point; courts have at times ordered a separation, ${ }^{24}$ and at other times permitted the jury to hear the evidence of former convictions at the trial stage. ${ }^{25}$

${ }^{2 x} 95$ Colo. 192, 34 P. (2d) 7 I (1934). Contra: Houston v. Commonwealth, $270 \mathrm{Ky}$. 125, I09 S.W. (2d) 45 (1937).

${ }^{22}$ For discussion and citation of statutes, see I Wigmore, Evidence $\$$ xg6 (3d ed. I940).

${ }^{23}$ This type of statute does not create an offense. It merely provides for increased punishment for successive convictions. People.v. Atkinson, 376 Ill. 623, 35 N.E. (2d) 58 (r94I); Ex parte Kuwitzky, I35 Neb. 466, 282 N.W. 396 ( 1938 ); State v. Woodman, I29 Kan. I66, 272 Pac. I32 (1928); Graham v. West Virginia, 224 U.S. 6 I6 (rgI2):

${ }^{24}$ Kan. Gen. Stat. Ann. (Corrick, 1935) $\$ \$ 21-107,21-107 a$, construed in State v. Woodman, I29 Kan. 166, 272 Pac. 132 (1928). Several states have enacted general habitual criminal statutes which do not indicate specifically whether the defendant's criminal history is to be heard by the court or the jury. With respect to this type of statute it has been held that the prior criminal convictions must be alleged in the indictment and proved during the trial. People v. Sickles, I56 N.Y. 54I, 5I N.E. 288 (1898). Some statutes contain a section providing that after sentence or conviction the district attorney may file an information alleging a criminal history in order to secure an increased sentence. Fla. Comp. Gen. Laws Ann. (Skillman, 1927) \$7108; La. Code Crim. Proc. Ann. (Dart, 1932) art. 7 Ir; N.M. Stat. Ann. (Courtright, 1929) \$35-4204; N.Y. Penal Law (McKinney, 1938) §1943; Ohio Code Ann. (Throckmorton, 1940) \$13744-3; Ore. Code Ann. (1940) \$26-2804. Under these statutes it appears to be the general practice not to allege the previous convictions in the original indictment. Shortly after conviction the state usually files a separate indictment alleging the previous convictions. People $\mathrm{v}$. Gowasky, 224 N.Y. 45I, I55 N.E. 737 (I927); State v. Smith, I28 Ore. 515, 273 Pac. 323 (I929); Cross v. State, 96 Fla. 758, I19 So. 380 (1928). Such a practice is to be approved, for it clearly recognizes the separation principle of trial and sentencing. However, there is nothing to prevent the filing of allegations of previous offenses in the original indictment under such a statute. United States ex rel. Wisniewsky v. Hunt, 36 F. Supp. 774 (N.Y. I94I). See People v. Gowasky, 224 N.Y. 451, I55 N.E. 737 (x927). Hence, whether or not the jury will be prejudiced by a showing of prior convictions will depend upon whether the prosecution desires to allege such a history in the original indictment or is willing to wait until after conviction before filing a separate indictment.

${ }^{25} \mathrm{Ky}$. Codes Ann. (Carroll, I9I5) §Ir30, construed in Oliver v. Commonwealth, $\mathrm{Ir}_{3} \mathrm{Ky}$ • 228, 67 S.W. 983 (I902); Neb. Comp. Stat. (I929) $\$ 29-2217$, construed in Taylor v. State, Ir4 Neb. 257,207 N.W. 207 (I926). 
A more desirable statute is one which specifically requires a separate procedure. This is accomplished by providing that that part of the indictment alleging previous convictions is not to be read to the jury until a verdict of guilty has been returned. Proof of the conviction is then made and if the jury finds after guilt has been established that the defendant is an habitual criminal, a heavier sentence is imposed. ${ }^{26}$ Though the jury is the body which determines whether or not the sentence is to be heavier, this procedure is in principle similar to the common law procedure. A few other statutes have specifically prohibited such a procedure. ${ }^{27}$

The indeterminate sentence also appears to be a recognition of the common law principle that the sentence is not part and parcel of the verdict but a distinct and separate act. Indeterminate sentence statutes ${ }^{28}$ do not call upon either the judge or the jury to fix the length of the sentence. The criminal is sentenced for a minimum-maximum term, and a parole or welfare board is called upon to determine when he shall be released. Such a board will not even consider the convict's case until he has served his minimum sentence. He will be released prior to the expiration of the maximum term only when the board is convinced he is fitted to take his place in society. Thus his time of release is not established until months or even years after his conviction. The board is not limited to the evidence in the trial record but is free to inquire closely into his past life.

Aside from enabling the court or jury to inquire into the past criminal record of the accused, the application of the separation principle would also afford the accused benefits which would otherwise be unavailable. Evidence of extenuating circumstances, which is inadmissible at trial because it is irrelevant to the issue of guilt or innocence, would be admissible at the sentence-fixing stage, since it is highly relevant with respect to the term of sentence to be given the defendant. ${ }^{29}$ Separation of the trial and sentence function would benefit the defendant in still another way. Although at trial a defendant is always permitted to introduce evidence as to his good general reputation, ${ }^{30}$ he is not allowed to introduce evidence of particular good acts-which may be far more valuable in determining his character than the opinions of others. ${ }^{3 \mathrm{I}}$ The fact

${ }^{26}$ Cal. Pen. Code (Deering, I94I) §1025; cf. Okla. Stat. (Harlow, I93I) §3140.

27 Ill. Rev. Stat. (I94I) c. $38, \S 602$; Ind. Stat. Ann. (Burns, I933) $\$ \S 9-2207,9-2208$, construed in Barr v. State, 205 Ind. $48 x$, I87 N.E. 259 (I933); Iowa Code (I93 I) \& r 3399.

${ }^{28}$ Cal. Pen. Code (Deering, I94r) $\$$ xx68; Ill. Rev. Stat. (I94r) c. 38 , $\$ 802 ;$ Ind. Stat. Ann. (Burns, r933) §9-1821; N.Y. Penal Law (McKinney, r938) §2189; Pa. Stat. Ann. (Purdon, 1930) tit. I9, § I057. These statutes are usually applicable to all but the most serious offenses. In Illinois an indeterminate sentence is to be imposed in all cases except misprision of treason, murder, rape, or kidnaping. Ill. Rev. Stat. (I94I) c. $38, \S 80$.

${ }^{29}$ State v. Smith, 2 Bay (S.C.) 62 (1796). Such facts are heard if raised by the issue. Most commonly such evidence is heard when insanity is pleaded in defense.

${ }^{30} \mathrm{I}$ Wigmore, Evidence $\$ 56$ (3 $\mathrm{d}$ ed. I940), and cases there cited.

3 Ibid., at $\S \mathrm{x} 95$, and cases there cited. 
that the proof of a number of individual good acts would introduce too many collateral issues has resulted in the exclusion of this type of evidence even though it is relevant to the likelihood of the defendant's committing a crime. ${ }^{32} \mathrm{How}-$ ever, at the sentencing stage the collateral issue danger would be outweighed by the great relevancy of such facts to the determination of a proper sentence. The amount of such evidence to be admitted could be left to the discretion of the court. ${ }^{33}$

The separation of the function of trying the accused from the function of sentencing the criminal has been recognized in the common law procedure, the desirable form of habitual criminal statute, the indeterminate sentence, the Popescue case, and the Dalhover case. The more widespread adoption of the principle of separating the two functions would seem to wait only upon its being brought more forcefully to the attention of the courts. Where a trial is before a jury there is no procedural reason in many states ${ }^{34}$ why a court if it so desired could not withhold objectionable character evidence from the jury during the trial and then admit this evidence after verdict for the purpose of determining the sentence. ${ }^{35}$ In those cases where a jury has been waived upon a plea of not guilty the court could impose similar restrictions upon itself..$^{36}$ When the plea is guilty the Popescue and Dalhover cases offer desirable precedents.

${ }^{32}$ Ibid., at $\$$ I95 n.4. Evidence which is only slightly relevant is excluded when it raises collateral issues. But as evidence becomes more relevant it is more likely to be admitted in spite of any collateral issues which might be raised. Detroit Iron \& Steel Co. v. Detroit Gray Iron Foundry Co., 240 Mich. 677, 216 N.W. 39I (1927).

33 As to appellate court rulings on a trial court's handling of relevant evidence in connection with the question of exclusion because of a policy rule, consult James, Relevancy, Probability and the Law, 29 Calif. L. Rev. 689, 70I-5 (I94I).

34 For example, under the following statutes there is no provision which would prevent the suggested procedure: Ala. Code Ann. (I940) tit. I4, $\$ 322$ (manslaughter); Ariz. Code Ann. (r939) $\S 43^{-2903}$ (murder); Cal. Pen. Code (Deering, I94I) § I9o (murder); Wash. Rev. Stat. Ann. (Remington, I932) $\$ 2392$ (murder). Such a procedure is not open in Illinois or Indiana because of a statutory requirement that the sentence be returned with the verdict by the jury. Note 15 supra. This is also the case under N.Y. Penal Law (McKinney, I938) § I045-a (murder); cf. People v. Hicks, 287 N.Y. I65, 38 N.E. (2d) 482 (I94I), noted in 9 Univ. Chi. L. Rev. 497 (1942).

35 Difficulties might arise under such a procedure if a jury were to return a verdict of guilty but be unable to decide upon the sentence to be imposed. The situation which obtains in a proceeding under an habitual criminal statute after sentence has been imposed, note 24 supra, would be somewhat analogous and would seem to indicate that no double jeopardy would be involved if a new jury were impaneled to pass solely upon the sentence. State v. Findling, I23 Minn. 4I3, I44 N.W. I42 (I9I3); Maguire v. State, 47 Md. 485, 497 (I877); Ingalls v. State, 48 Wis. 647,4 N.W. 785 (I880); People v. Stanley, 47 Cal. Ix $_{3}$ (I874).

${ }^{36}$ State v. Reeder, 79 S.C. 139, 60 S.E. 434 (I908); Fields v. State, 47 Ala. 603 (I872). Such a procedure might be open in the Illinois courts today. In the light of People v. Popescue, 345 IIl. I42, I 77 N.E. 739 (I93I), page 718 supra, it would appear that the outcome of People v. Corry, 349 Ill. I22, $18 \mathrm{r}$ N.E. 603 (I932), note 9 supra, would have been different had the trial judge imposed such restrictions upon himself rather than admitting the prejudicial evidence prior to his determination of guilt. 
Perhaps from the standpoint of general policy the ideal solution of the problem of fixing the sentence and yet excluding objectionable character evidence would involve a return through legislation to the common law procedure whereby the court alone had the function of determining the length of sentence. ${ }^{37}$ This would place this important task in more experienced and dispassionate hands, although it might suffer from the disadvantage that a jury would be less likely to convict where it did not have control of the length of sentence to be given the accused. Whether the court or the jury is to fix the sentence, an adherence to the separation principle as suggested would.afford the defendant the full benefit of the undue prejudice rule and also would give the sentencing body the pertinent facts, both favorable and unfavorable to the criminal, necessary for the proper exercise of the discretion given it by the legislature. ${ }^{38}$

37 Ariz. Code Ann. (1939) §44-2208; Colo. Stat. Ann. (Michie, I935) c. 48, §515; La. Code Crim. Proc. Ann. (Dart, I932) art. 526; Mass. Ann. Laws (I933) c. 279, $\$ 5$; Federal Rules of Criminal Procedure after Plea of Guilty, Verdict or Finding of Guilt, Rule I, I8 U.S.C.A. following $\$ 688$ (Supp. r94r).

38 "Any person indicted stands before the bar of justice clothed with a presumption of innocence and, as such, is tenderly regarded by the law. Every safeguard is thrown about him. .... After a plea of guilty admitted murderers are in a much different position. As such they are felons. Instead of being clothed with a presumption of innocence they are naked criminals, hoping for mercy but entitled only to justice." Shaw, J., in People v. Riley, 376 Ill. 364, 368, 33 N.E. (2d) 872,875 (194r). 